\title{
ANTIBIOTIC AND PHYTOTOTOXIC ACTIVITIES OF CULTURAL FILTRATES OF SOME MICROMYCETE STRAINS
}

\author{
I.G. Rubezhniak \\ National University of Life and Environmental sciences of Ukraine, \\ 15 Heroyiv Oborony st., Kyiv, 03041, Ukraine \\ e-mail: rubezhnyak60@gmail.com
}

The aim of work was to test the antibiotic and phytotoxic activity of cultural filtrates of 125 micromycete strains isolated from different ecological niches. Methods. The activity was studied using different test-organisms - Gram-negative phytopathogenic bacteria, yeasts and green algae. Results. It is shown that 57 cultures were developed biological activities only. The wide spectrum of antibiotic action and middle antifungal activity was characterized for the cultures of genus Aspergillus and Penicillium. A fungistatic activity was shown only by strains as A. parvulus 31, A. versicolor 60, P. brevicompactum 144, P. rubrum 91and 93. A significant group consisted of cultures with phytotoxic activity: A. alliaceus 16, A. parvulus 30, A. versicolor 56, Aureobasidium pullulans 41 and 44, Chaetomium globosum 38, Curvularia inaequalis 84, Fusarium merismoides 151, Mortirella vinacea 74 and 82, Paecilomyces lilacinus 127, P. chrysogenum 163. Most strains with antibiotic activity did not show phytotoxic activity against test culture. Conclusions. As it is no findings about phytotoxic effect of strains of A. pullulans and $M$. vinacea and from the data obtained it might be inferred that the phytotoxic potential of these genus to be the most promising for further researches.

Keywords: micromycetes, antibiotic activity, phytotoxic activity, test-organisms.

During the second century the identification of micromycetes that produce bioactive compounds is of great interest in the finding of new molecules to fight against many plant diseases. Fungi produce a wide range of metabolites as enzymes, antibiotics, vitamins, cytotoxic substances, insecticides, compounds that promote or inhibit growth, attractor, repellent, etc. [1,2].

System researches concerning ability to produce the biologically active substances were conducted by different authors on the separate strains of molds $[2,3]$. Wide potential of micromycetes had not been fully studied up to now.

Intensive use of chemicals such as fertilizers and pesticides in agriculture forwards to increase of anthropogenic load of the environment. Chemicals accumulate in plants and pass to human beings cause intoxication, chronic diseases and cancer. The elimination of these consequences is possible only through a search new high- performance and ecologically safe chemicals as biopesticides.

The aim of our work was to test the antibiotic and phytotoxic activity of cultural filtrates of 125 micromycete strains as a starting point for further investigations of the most perspective strains for feasible obtaining of biopesticides. 
Materials and methods. In this work it was used 125 micromycete strains of the genus Penicillium, Cladosporium, Botrytis, Beauveria, Chaetomium, Curvularia, Endomyces, Fusarium, Gliocladium, Aspergillus, Alternaria, Aureobasidium, Paecilomyces, Mortirella, Nigrospora, Pseudallescheria, Scopulariopsis, Trichoderma, Ulocladium and separate strains Nectria sp., Phialophora sp. and Verticillium dahliae, which were isolated from different ecological niches such as air, dwelling walls, soil of Chernigovska area and rhizosphere of plants.

The micromycetes were grown on a basic nutritive Czapek medium [5]. The culture media were distributed in Erlenmeyer flasks $(250 \mathrm{ml})$ with $50 \mathrm{ml}$ medium. For inoculation ten-day suspension $\left(1 \times 10^{8}\right.$ cells per $\left.\mathrm{ml}\right)$ of micromycetes grown on Czapek medium by $26^{\circ} \mathrm{C}$ were used. After 14 days the mycelium was removed through filtration. The culture liquid filtrates were tested against Gram-negative phytopathogenic bacteria such as Agrobacterium tumefaciens 8464 and Pectobacterium carotovorum 8636. A. tumefaciens causes crown gall disease on various plant species and $P$. carotovorum is a ubiquitous plant pathogen with a wide host range (carrot, potato, tomato, leafy greens, etc.). Antifungal activity was tested using test culture of yeast Trichosporon cutaneum 1502. Phytotoxic properties of culture liquid filtrates were studied using green algae Chlorella vulgaris 190 [5].

Bacterial test organisms have been incubated on the medium of agarose gel for 24 hours. The yeast strain have been grown on wort agar at $26^{\circ} \mathrm{C}$ for 48 hours, the algal culture was grown in test tubes on a medium [5] at $26^{\circ} \mathrm{C}$ and illumination of 4000 lux for 5 days.

The screening study of culture liquid filtrate of micromycete strains using standard agar well diffusion method was followed. Eight-millimetre diameter wells were cut from the agar using a sterile cork-borer, and $100 \mu$ of filtrate were delivered into the wells [5]. A diameter of inhibition zones of Petri dish culture was measured. The inhibition zones of bacteria were measured after 18-24 hours. In a similar way, the antifungal activity of culture liquid filtrates using yeast after 48 hours of incubation was studied. Phytotoxic properties of culture liquid filtrates were determined after incubation of Petri dishes with C. vulgaris 190 for $48-72$ hours.

Bacterial and yeast strains were collected from the Department of Physiology and Taxonomy of Micromycetes, Danylo Zabolotny Institute Microbiology and Virology NAS of Ukraine.

Results. It can be seen in Table 1 that only 57 from 125 strains shown antibiotic activity and inhibit the growth of test organisms. Among them, strains such as A. alternata 116, A. pullulans 41, C. cladosporiodes 8 and 9, F. merismoides f. merismoides 151, P. variotii 67-69, P. aculeatum 123 and 124, P. funiculosum 1-6, P. brevicompactum 144, P chrysogenum 163, P. ochrochloron 145 and 156, P. purpurogenum 143, T. harzianum 157 and $V$. dahlia 168 have a broad spectrum of antibiotic activity against phytopathogenic bacteria. 
The separate strains such as $A$. alleaceum $118, A$. parvulus $31, A$. terreus 119, A. versicolor 58 and 61, A. pullulans 43-46, M. vinacea 62 - 63, P. funiculosum 7, P. rubrum 91 and T. viride 120 displayed antibiotic activity against $P$. carotovorum only. These strains didn't show the antifungal and phytotoxic activities except $A$. parvulus 31 . The strains as $A$. parvulus 30 , $A$. versicolor 60 and $G$. virens 39 shown antibiotic activity against A. tumefaciens (inhibition zone is 30, 13 and 18, respectively). Most strains inhibited the growth of bacteria for 24-48 hours (bacteriostatic activity).

The strains of the genus Aspergillus such as A. parvulus 31, A. versicolor 60, Penicillium genus such as P. brevicompactum 144 and P. rubrum 91, 93 showed fungistatic activity against $T$. cutaneum 1502 (inhibition zone from 15 to $10 \mathrm{~mm}$ ). Strains of $C$. cladosporiodes 10 and 11 also visualized very weak fungistatic effect.

The study of phytotoxic effect of micromycete strains indicated that A. alliaceus 16, A. parvulus 30, A. versicolor 56, A. pullulans 41 and 44, C. globosum 38, C. inaequalis 84, F. merismoides 151, M. vinacea 74 and 82, P. lilacinus 127, P. chrysogenum 163 and $V$. dahlia 168 demonstrate the strong phytotoxic activity. Other strains showed a small phytotoxic activity and had small size of inhibition zones of the test culture (A. parvulus 31, A pullulans 42, $B$. cinerea $55, M$. vinacea 73 and other). Most strains with antibiotic activity did not show phytotoxic activity against test culture.

The strains of B. bassiana, F. lactis, F. solani, Nectria sp., N. oryzae, P. marquandii, P. clavigerum, P. ucrainicum, Phialophora sp., P. boydii, $S$. brumptii, $U$. atrum and $U$. consortiale did not display antibiotic and phytotoxic activity.

Discussion. The finding shows that micromycete strains have a large spectrum of biological active substances. The results demonstrated that representatives of the genus Aspergillus and genus Penicillium are characterized by high antibiotic activity against phytotoxic bacteria and middle antifungal activity. Only some strains of genus Aspergillus as A. alliaceus 16, A. versicolor 56, A. parvulus 30 and genus Penicillium as P. aculeatum 124, $P$. chrysogenum 163 and $P$. ochrochloron 156 have a remarkable phytotoxic activity against $C$. vulgaris 190 . Our experiments are consistent with previous results $[6,7]$. Tsyganenko shown that Aspergillus strains had a wide spectrum of antibiotic action and phytotoxic activity especially A. parvulus 3142 $[6,7]$. Screening of antifungal activity against yeast-like fungi had shown only single displays of this activity [6]. Some authors have also suggested that all chloroform extracts of the tested isolates of Aspergillus and Penicillium species had antifungal effect against Fusarium spp. growth where those from $P$. chrysogenum and A. flavus had decreased their radial growth by $76 \%$ compared to their relative controls [8]. The literature review shows that extracts of cultural filtrates of $A$. niveus 2411 and Penicillium sp. 1051 have been shown the activity concerning phytopathogenic bacteria $A$. tumefaciens 8464 . Note should be taken that the traditional methods of controlling of phytopathogenic 
bacteria such as metal-containing pesticides were not effective [9]. Therefore, the investigation of antibiotic activity of Aspergillus and Penicillium species against phytopathogenic bacteria and their practical use deserve attention.

Another promising finding was that species of the genus Aureobasidium and genus Mortirella are characterized by antibiotic and phytotoxic activity. It was reported in literature that a strain of $A$. pullulans is used to produce a cyclic peptide that has specific antifungal activity: aureobasidin A [10]. Due to its strong antagonistic activity against other microorganisms, A. pullulans is used as a biocontrol agent in agriculture [10]. Additionally, a recent study reported that some strains of $A$. pullulans can produce an antibacterial compound, exophilin A, as well as high yields of liamocins, and heavy oils. A. pullulans has a high importance in biotechnology to produce different enzymes, siderophores and pullulan [11]. Furthermore, A. pullulans is used in biological control of plant diseases, especially storage diseases $[12,13]$. In recent years there has been considerable interest in strains of $A$. pullulans as biopesticides. A proprietary mixture of two strains of A. pullulans was recently registered in the U.S. under the trade name "Blossom Protect" as a biocontrol to prevent blossom infections by Erwinia amylovora, the fire blight pathogen. Blossom Protect has been used successfully both Europe and in the Pacific Northwest. The new Botector Fungicide contains yeast-like fungi, A. pullulans strains DSM 14940 and DSM 14941, as the active constituent [14]. Botector Fungicide is a biological fungicide intended for use as a preventative treatment in the control of botrytis bunch rot / grey mould (B. cinerea) in grapes.

There has been considerable interest in antibiotic potential of $M$. vinacea in recent years [15]. The known compound methyl 2,4-dihydroxy-3,5,6trimethylbenzoate and three new related metabolites, which were named mortivinacins A, B and C, were identified as metabolites of the fungus M. vinacea. Nicotinic acid was also encountered. Methyl 2,4-dihydroxy-3,5,6trimethylbenzoate, mortivinacins A and nicotinic acid were responsible for the antibacterial and antifungal activities of the extract. Our results suggest that cultural filtrates of strains of $A$. pullulans and $M$. vinacea possess marked antibacterial activity as well as phytotoxic activity. It must also be noted that it is no findings about phytotoxic effect of strains of $A$. pullulans and $M$. vinacea.

This study has gone some way towards enhancing our understanding of biologically active substances by micromycete strains. It will be important to carry on the further research of metabolites of Aspergillus and Penicillium strains, shown antibacterial or phytotoxic activity, which can afford a basis for obtaining of biopesticides.

To further our research, we intend to study the phytotoxic cultural filtrates and extracts of micromycetes using a wide spectrum of crops and weeds. More broadly, research is also needed to determine the phytotoxic potential of strains of $A$. pullulans and $M$. vinacea. The literature on phytotoxic activity of strains of the genus Aureobasidium and Mortirella is absent. It is interesting to test the strains of $A$. pullulans and $M$. vinacea against a range of negative and positive bacteria also. 
Table 1

Antibiotic and phytotoxic activities of cultural filtrate of micromycetes

\begin{tabular}{|c|c|c|c|c|c|c|}
\hline \multirow[b]{2}{*}{$\begin{array}{l}\text { No } \\
\Pi \text { ח/ா }\end{array}$} & \multirow[b]{2}{*}{ Species } & \multirow[b]{2}{*}{ Strains } & \multicolumn{4}{|c|}{$\begin{array}{c}\text { Diameter of inhibition zones } \\
\text { of test, } \mathrm{mm}\end{array}$} \\
\hline & & & 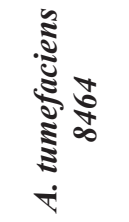 & 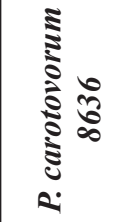 & 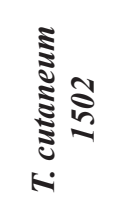 & ن \\
\hline 1 & 2 & 3 & 7 & 8 & 9 & 10 \\
\hline 1 & Alternaria alternata & 116 & $16,0 \pm 0,7$ & $11,0 \pm 0,9$ & 0 & 0 \\
\hline 2 & Aspergillus alliaceus & 16 & 0 & 0 & 0 & $22,0 \pm 2,7$ \\
\hline 3 & & 118 & 0 & $15,0 \pm 1,0$ & 0 & 0 \\
\hline 4 & A. parvulus & 30 & $30,0 \pm 0,7$ & 0 & 0 & $16,0 \pm 0,7$ \\
\hline 5 & & 31 & 0 & $24,0 \pm 2,0$ & $15,0 \pm 0,7$ & $12,0 \pm 3,0$ \\
\hline 6 & A. terreus & 119 & 0 & $15,0 \pm 2,0$ & 0 & 0 \\
\hline 7 & A. versicolor & 56 & 0 & 0 & 0 & $20,0 \pm 1,0$ \\
\hline 8 & & 58 & 0 & $17,5 \pm 0,5$ & 0 & 0 \\
\hline 9 & & 60 & $13,0 \pm 1,0$ & \begin{tabular}{|l|}
0 \\
\end{tabular} & $12,0 \pm 2,0$ & $9,0 \pm 1,0$ \\
\hline 10 & & 61 & 0 & $19,0 \pm 3,0$ & 0 & 0 \\
\hline 11 & A. ustus & 101 & 0 & $13,0 \pm 1,0$ & 0 & 0 \\
\hline 12 & & 102 & 0 & $15,0 \pm 2,0$ & 0 & 0 \\
\hline 13 & & 103 & 0 & $15,0 \pm 1,0$ & 0 & 0 \\
\hline 14 & Aureobasidium pullulans & 41 & $30,0 \pm 0,8$ & $25,0 \pm 1,0$ & 0 & $17,3 \pm 0,9$ \\
\hline 15 & & 42 & 0 & 0 & 0 & $13,0 \pm 1,0$ \\
\hline 16 & & 43 & 0 & $15,7 \pm 0,4$ & 0 & 0 \\
\hline 17 & & 44 & 0 & $10,8 \pm 0,4$ & 0 & $19,0 \pm 0,7$ \\
\hline 18 & & 45 & 0 & $20,0 \pm 0,7$ & 0 & 0 \\
\hline 19 & & 46 & 0 & $20,0 \pm 0,7$ & 0 & 0 \\
\hline 20 & Botrytis cinerea & 55 & 0 & \begin{tabular}{|l|}
0 \\
\end{tabular} & 0 & $11,0 \pm 1,0$ \\
\hline 21 & Chaetomium globosum & 38 & 0 & 0 & 0 & $22,0 \pm 3,0$ \\
\hline 22 & Cladosporium cladosporiodes & 8 & $30,0 \pm 1,0$ & $10,0 \pm 1,0$ & 0 & 0 \\
\hline 23 & & 9 & $10,7 \pm 0,3$ & $12,0 \pm 2,0$ & 0 & 0 \\
\hline 24 & & 10 & 0 & 0 & $7,0 \pm 0,3$ & 0 \\
\hline 25 & & 11 & 0 & 0 & $9,0 \pm 0,3$ & 0 \\
\hline 26 & Gliocladium virens & 39 & $18,0 \pm 1,0$ & 0 & 0 & 0 \\
\hline 27 & Curvularia inaequalis & 84 & 0 & 0 & 0 & $19,0 \pm 2,0$ \\
\hline 28 & $\begin{array}{l}\text { Fusarium merismoides } \\
\text { f. merismoides }\end{array}$ & 151 & $15,0 \pm 0,3$ & $16,0 \pm 1,0$ & 0 & $20,0 \pm 2,0$ \\
\hline 29 & Mortirella vinacea & 62 & 0 & $22,0 \pm 1,0$ & 0 & 0 \\
\hline 30 & & 63 & 0 & $24,0 \pm 1,0$ & 0 & 0 \\
\hline 31 & & 73 & 0 & \begin{tabular}{|l|}
0 \\
\end{tabular} & 0 & $13,0 \pm 0,7$ \\
\hline 32 & & 74 & 0 & 0 & 0 & $25,0 \pm 0,7$ \\
\hline 33 & & 82 & 0 & 0 & 0 & $15,0 \pm 0,1$ \\
\hline 34 & Paecilomyces variotii & 67 & $12,7 \pm 0,1$ & $10,0 \pm 1,0$ & 0 & 0 \\
\hline 35 & & 68 & $30,0 \pm 1,0$ & $20,0 \pm 0,7$ & 0 & 0 \\
\hline 36 & & 69 & 0 & $10,7 \pm 0,8$ & 0 & 0 \\
\hline 37 & P. lilacinus & 127 & 0 & 0 & 0 & $21,0 \pm 1,0$ \\
\hline 38 & Penicillium aculeatum & 123 & $12,0 \pm 0,7$ & $14,0 \pm 1,0$ & 0 & 0 \\
\hline 39 & & 124 & $20,0 \pm 2,0$ & $11,0 \pm 0,7$ & 0 & $14 \pm 0,7$ \\
\hline 40 & P. brevicompactum & 144 & $13,0 \pm 2,0$ & $17,0 \pm 2,0$ & $10,0 \pm 1,3$ & 0 \\
\hline
\end{tabular}




\begin{tabular}{|l|c|c|c|c|c|c|}
\hline 41 & P. funiculosum & 1 & $15,0 \pm 2,0$ & $12,0 \pm 0,7$ & 0 & 0 \\
\hline 42 & & 2 & $32,0 \pm 1,0$ & $9,0 \pm 0,3$ & 0 & 0 \\
\hline 43 & & 3 & $18 \pm 0,7$ & $19,3 \pm 0,7$ & 0 & 0 \\
\hline 44 & & 4 & $16,7 \pm 0,4$ & $16,3 \pm 0,4$ & 0 & 0 \\
\hline 45 & & 5 & $16,3 \pm 0,4$ & $15,3 \pm 0,4$ & 0 & 0 \\
\hline 46 & & 6 & $17,0 \pm 0,7$ & $17,7 \pm 1,1$ & 0 & 0 \\
\hline 47 & & 7 & 0 & $11,0 \pm 0,7$ & 0 & 0 \\
\hline 48 & P. chrysogenum & 163 & $39,0 \pm 0,7$ & $14,0 \pm 0,7$ & 0 & $24,3 \pm 1,1$ \\
\hline 49 & P. ochrochloron & 145 & $12,0 \pm 0,7$ & $13,7 \pm 0,1$ & 0 & 0 \\
\hline 50 & & 156 & $20,0 \pm 0,7$ & $11,0 \pm 1,3$ & 0 & $13 \pm 0,7$ \\
\hline 51 & P. purpurogenum & 143 & $12,0 \pm 1,3$ & $11,7 \pm 0,4$ & 0 & 0 \\
\hline 52 & P. rubrum & 91 & 0 & $20,0 \pm 1,3$ & $13,0 \pm 0,7$ & 0 \\
\hline 53 & & 93 & 0 & 0 & $11,0 \pm 0,7$ & 0 \\
\hline 54 & Trichoderma harzianum & 157 & $23,0 \pm 0,7$ & $17,7 \pm 0,4$ & 0 & $12,3 \pm 0,9$ \\
\hline 55 & T. viride & 120 & 0 & $15,0 \pm 0,7$ & 0 & 0 \\
\hline 56 & Trichoderma sp. & 147 & 0 & 0 & 0 & 0 \\
\hline 57 & Verticillium dahliae & 168 & $11,0 \pm 0,7$ & $17,7 \pm 0,4$ & 0 & $19,0 \pm 0,7$ \\
\hline
\end{tabular}

\section{АНТИБІОТИЧНА ТА ФІТОТОКСИЧНА АКТИВНОСТІ КУЛЬТУРАЛЬНИХ ФІЛЬТРАТІВ ДЕЯКИХ ШТАМІВ МІКРОМЦЕТІВ}

\section{І.Г. Рубежняк}

Національний університет біоресурсів та природокористування Украӥни, вул. Героїв Оборони, 15, Київ, 03041, Украӥна

\section{Резюме}

Метою роботи був скринінг 125 штамів мікроміцетів, виділених з різних екологічних ніш, на антибіотичну та фітотоксичну активності. Методи. Активність вивчалася з використанням різних тест-організмів - грамнегативних фітопатогенних бактерій, дріжджів і зелених водоростей. Результати. Показано, що тільки 57 досліджуваних штамів проявили біологічну активність. Широким спектром антибіотичної дії і помірною антифунгальною активністю характеризувалися досліджувані штами роду Aspergillus та Penicillium. Фунгістатичну дію проявляли штами A. parvulus 31, A. versicolor 60, P. brevicompactum 144, P. rubrum 91 і 93. Значну групу складали штами $з$ фітотоксичною активністю - A. alliaceus 16 , A. parvulus 30 , A. versicolor 56 , Aureobasidium pullulans 41 i 44, Chaetomium globosum 38, Curvularia inaequalis 84, Fusarium merismoides 151, Mortirella vinacea 74 i 82, Paecilomyces lilacinus 127, P. chrysogenum 163. Більшість штамів з антибіотичною активністю не показали фітотоксичної дії. Висновки. Найбільш перспективними для подальших досліджень $€$ штами A. pullulans та M. vinacea, які проявляють фітотоксичну активність, що раніше не досліджувалось.

Ключові слова: мікроміцети, антибіотична активність, фітотоксична активність, тест-організми. 


\title{
АНТИБИОТИЧЕСКАЯ И ФИТОТОКСИЧЕСКАЯ АКТИВНОСТИ КУЛЬТУРАЛЬНЫХ ФИЛЬТРАТОВ НЕКОТОРЫХ ШТАММОВ МИКРОМИЦЕТОВ
}

\author{
И.Г. Рубежннк \\ Национальный университет биоресурсов и природопользования Украины, \\ ул. Героев Обороны, 15, Киев, 03041, Украина \\ Резюме
}

Целью работы был скрининг 125 штаммов микромицетов, выделенных из разных экологических ниш, по антибиотической и фитотоксической активности. Методы. Активность изучалась с использованием различных тест-организмов - грамотрицательных фитопатогенных бактерий, дрожжей и зеленых водорослей. Результаты. Показано, что только 57 исследуемых штаммов проявили биологическую активность. Широким спектром антибиотического действия и умеренной антифунгальной активностью характеризовались исследуемые штаммы рода Aspergillus and Penicillium. Фунгистатическое действие проявляли только штаммы A. parvulus 31 , A. versicolor 60 , P. brevicompactum 144, Р. rubrum 91 и 93. Значительную группу составляли штаммы с фитотоксической активностью - A. alliaceus 16 , A. parvulus 30 , A. versicolor 56 , Aureobasidium pullulans 41 и 44, Chaetomium globosum 38, Curvularia inaequalis 84, Fusarium merismoides 151, Mortirella vinacea 74 и 82, Paecilomyces lilacinus 127 , P. chrysogenum 163. Большинство штаммов с антибиотической активностью не проявляли фитотоксическое действие. Выводы. Наиболее перспективными для дальнейших исследований являются штаммы A. pullulans и M. vinacea, которые проявляют фитотоксическую активность, что раньше не исследовалось.

Ключевые слова: микромицеты, антибиотическая активность, фитотоксическая активность, тест-организмы.

1. Mérillon J-M, Ramawat KG, editors. Fungal Metabolites. Switzerland :Springer International Publishing; 2017

2. Rubezhniak IG. [Some features of secondary metabolism of microorganisms]. In: Akutina SP, editor. Selected issues of modern science. Part 3. Monography In: Moscow: Pero; 2011. p. 283-310. Russian.

3. Tsyganenko KS, Zaichenko OM. Antybiotychni vlastyvosti deiakykh vydiv rodu Aspergillus Mich. Mikrobiol. Z. 2004; 66(4):56-61. Ukrainian.

4. Tsyganenko KS. Otsinka antybiotychnoho potentsialu Aspergillus parvulus Smith. Naukovyi visnyk Chernivetskoho un-tu. Ser. Biolohiia. 2004; 194:33-36. Ukrainian.

5. Bilay VI, editor. [Methods of experimental mycology]. Kiev: Naukova Dumka; 1982. Ukrainian.

6. Tsyganenko KS. The evaluation of antibiotic and toxigenic potential of some species micromycetes of genera Aspergillus Mich. [author's abstract]. Danilo Zabolotny Institute of Microbiology and Virology of National Academy of Sciences of Ukraine: Kyiv; 2005. Ukrainian.

7. Tsyganenko KS, Zaichenko OM. Kharakterystyka fitotoksychnykh vlastyvostei Aspergillus parvulus Smith. Ahroekol. Z. 2004; 4:42-45. Ukrainian. 
8. Mejdoub-Trabelsi B, Rania Aydi Ben A, Nawaim A, Mejda Daami R. Antifungal potential of extracellular metabolites from Penicillium spp. and Aspergillus spp. naturally associated to potato against Fusarium species causing tuber dry rot. J. Microb. Biochem. Technol. 2017; 9:181-190.

9. Savchuk YaI, Zaichenko OM, Tsyganenko KS. [Antibiotic activity of some fungy]. Mikrobiol. Z. 2013; 75(5):52- 61. Ukrainian

10. Gostinčar C, Ohm RA, Kogej T, Sonjak S, Turk M, Zajc J, et al. Genome sequencing of four Aureobasidium pullulans varieties: biotechnological potential, stress tolerance, and description of new species. BMC Genomics. 2014;15:549-577.

11. Chi Z, Wang F, Chi Z, Yue L, Liu G, Zhang T. Bioproducts from Aureobasidium pullulans, a biotechnologically important yeast. Applied microbiology and biotechnology.2009;82 (5):793-804.

12. Ferreira-Pinto MM, Moura-Guedes MC, Barreiro MG, Pais I, Santos MR, Silva M J. Aureobasidium pullulansas a biocontrol agent of blue mold in "Rocha" pear". Communications in agricultural and applied biological sciences.2006; 71(3 Pt B): 973-978.

13. Zhang D, Spadaro D, Valente S, Garibaldi A, Gullino ML. Cloning, characterization, expression and antifungal activity of an alkaline serine protease of Aureobasidium pullulans PL5 involved in the biological control of postharvest pathogens. Int. J. of Food Microbiology. 2012; 153 (3):453-464.

14. Australian Pesticides and Veterinary Medicines Authority. Public release summary on the evaluation of the new active Aureobasidium pullulans (strains DSM 14940 and DSM 14941) in the product Botector Fungicide; August 2017.

15. Soman AG, Gloer JB, Wicklow DT. Antifungal and Antibacterial Metabolites from a Sclerotium-Colonizing Isolate of Mortierella vinacea. J. Nat. Prod.1999; 62 (2):386388 .

Отримано 23.05.2017 